\title{
FONTES DE NITROGÊNIO NA MICROPROPAGAÇÃO DE Coffea arabica'
}

\section{NITROGEN SOURCES IN COFFEE MICROPROPAGATION}

\author{
Lilian de Sousa RIBEIRO² \\ Moacir PASQUAL ${ }^{3}$ \\ Anna Lygia de Rezende MACIEL ${ }^{4}$ \\ Evaldo de Sousa ARANTES ${ }^{5}$ \\ Edvan Alves $\mathrm{CHAGAS}^{4}$
}

\begin{abstract}
RESUMO
Considerando que o meio de cultura usado para a propagação de culturas in vitro tem uma alta concentração em minerais, aliado a um custo elevado e à dificuldade de aquisição de nitrato e amônio, objetivouse reduzir a proporção de fontes de nitrogênio $\left(\mathrm{NH}_{4} \mathrm{NO}_{3}\right.$ e $\left.\mathrm{KNO}_{3}\right)$ usadas no meio de cultura de segmentos nodais de Coffea arabica L. cv Rubi. Explantes $(2 \mathrm{~cm})$ preestabelecidos in vitro foram inoculados em tubos de ensaio contendo meio de cultura MS acrescido de $\mathrm{NH}_{4} \mathrm{NO}_{3}$ e $\mathrm{KNO}_{3}(0,25,50,75$, e $100 \%)$ e mantidos em sala de crescimento com $27 \pm 1^{\circ} \mathrm{C}$ e $32 \mu \mathrm{M}^{-2} \mathrm{~m}^{-2} . \mathrm{s}^{-1}$ de intensidade luminosa por 16 horas diárias. Após 60 dias avaliaram-se o número total de brotos, o peso da matéria fresca da parte aérea e o peso da matéria seca total. Há possibilidade de redução da concentração de $\mathrm{NH}_{4} \mathrm{NO}_{3}$ para $50 \%$ e de $\mathrm{KNO}_{3}$ para $75 \%$.
\end{abstract}

Palavras-chave: cafeeiro, segmento nodal, cultura de tecidos, meio MS.

\begin{abstract}
Considering that the MS medium is very rich in mineral salts ally to the high cost and the difficulty in the acquisition of nitrate and ammonium it was aimed at to reduce the concentration of two sources of nitrogen $\left(\mathrm{NH}_{4} \mathrm{NO}_{3}\right.$ and $\left.\mathrm{KNO}_{3}\right)$ used in the culture medium of nodal segments of Coffea arabica L. cv. Rubi. Explants $(2 \mathrm{~cm})$ preestablished in vitro were inoculated in $\mathrm{MS}$ medium with $\mathrm{NH}_{4} \mathrm{NO}_{3}$ and $\mathrm{KNO}_{3}(0,25,50,75$ and $100 \%$ ) and maintained at growth room with $27 \pm 1^{\circ} \mathrm{C}$ temperature and 16 hours/day under $32 \mathrm{mM} \cdot \mathrm{m}^{-2} \cdot \mathrm{s}^{-1}$ light intensity. After 60 days were evaluated the total number of sprouts, the aerial part fresh matter weight and the total dry matter weight. Its possible to reduce the $\mathrm{NH}_{4} \mathrm{NO}_{3}$ concentration to $75 \%$ and $\mathrm{KNO}_{3}$ to $50 \%$.
\end{abstract}

Key-words: Coffee plant, nodal segment, tissue culture, MS medium.

\footnotetext{
${ }^{1}$ Suporte financeiro do CBP\&D Café e FAPEMIG.

${ }^{2}$ Depto de Biologia/UFLA, doutoranda em Fisiologia Vegetal.

${ }^{3}$ Depto de Agricultura/UFLA, Lab. Cultura de tecidos. Campus Universitário, CEP 37200-000. Lavras-MG. Tel. 3538291323. e-mail: <mpasqual@ufla.br>

${ }^{4}$ Depto de Agricultura/UFLA, mestrando em Fitotecnia.

${ }^{5}$ Depto de Agricultura/UFLA, Laboratorista/Laboratório de Cultura de Tecidos.
} 
RIBEIRO, L.S. et al. Fontes de nitrogênio na micropropagação...

\section{INTRODUÇÃO}

O papel do nitrogênio no crescimento e desenvolvimento das plantas é amplamente reconhecido. Entretanto, a forma de suprimento de nitrogênio (fixação de $\mathrm{NH}_{4}^{+}, \mathrm{NO}_{3}^{-}$e $\mathrm{N}_{2}$ ) está correlacionada com a relação cátion-ânion na planta, onde $70 \%$ dos cátions e ânions absorvidos são representado por $\mathrm{NH}_{4}^{+}$e $\mathrm{NO}_{3}^{-}(18)$.

Diversas formulações de meios básicos têm sido amplamente utilizadas no cultivo in vitro. No entanto, não há uma formulação padrão para o meio Murashige e Skoog-MS (13), sendo que suas modificações e diluições têm apresentado bons resultados para diversas espécies, sendo que as variações mais freqüentes do meio básico dizem respeito à composição de macronutrientes (10). Embora o MS seja o mais comumente utilizado para a propagação de várias espécies, sua concentração de nutrientes tem sido identificada como elevada, principalmente quanto ao fornecimento de $\mathrm{N}$ e, neste sentido, muitas modificações tem sido sugeridas objetivando maior adaptação das culturas e redução dos custos (9).

Alguns autores reportaram que o nitrato, como única fonte de $\mathrm{N}$, sustenta uma satisfatória taxa de crescimento em muitas espécies, sendo, também, a melhor forma de suprimento de $\mathrm{N}$ para algumas culturas, tais como cenoura, fumo, Populus, roseira e várias outras espécies (4).

Quando o N é fornecido somente na forma de sais inorgânicos de amônio, as células in vitro apresentam sintomas de toxidez $(7,19)$. A mesma concentração de amônio, que é tóxica ou inibitória quando a concentração de nitrato é baixa, permite bom crescimento quando aumenta a sua concentração (3), evidenciando a essencialidade da combinação das duas formas de N, amônio e nitrato, no crescimento de plantas in vitro (19).

As cultivares de Coffea arabica L. são predominantemente autopolinizadas e, portanto, bastante uniformes, razão pela qual são comumente propagadas por sementes. Entretanto, em qualquer programa de melhoramento genético, materiais elites podem ser identificados e como ainda não estão em homozigose só poderiam ser multiplicados vegetativamente, oportunidade em que a cultura de tecidos se apresentaria como vantajosa.

A micropropagação é a aplicação mais prática da cultura de tecidos, através da qual pode-se obter grande número de plantas sadias e geneticamente uniformes. A utilização de microestacas vem sendo utilizada em inúmeros trabalhos com micropropagação de cafeeiro $(1,2,14)$. A maioria das plantas micropropagadas é obtida pela multiplicação de brotos axilares (8). A multiplicação de brotos é um método seguro que pode ser usado quando a produção de clones de plantas lenhosas for requerida.

Considerando que as plantas tendem a responder diferentemente às formas minerais de $\mathrm{N} e$, que a quantidade de $\mathrm{N}$ fornecida na forma de nitrato e amônio no meio de cultura MS é elevada, aliado ao seu alto custo e dificuldade de aquisição, objetivouse reduzir a concentração de duas fontes de $\mathrm{N}$ $\left(\mathrm{NH}_{4} \mathrm{NO}_{3}\right.$ e $\left.\mathrm{KNO}_{3}\right)$ usadas no meio de cultura de segmentos nodais de Coffea arabica L. cv Rubi.

\section{MATERIAL E MÉTODOS}

Segmentos nodais de Coffea arabica L. cv. Rubi com $2 \mathrm{~cm}$ de comprimento, provenientes de plântulas preestabelecidas in vitro, foram inoculadas em tubos de ensaio $(25 \times 150 \mathrm{~mm})$, com $15 \mathrm{~mL}$ de meio de cultura. Os tratamentos consistiram da interação de concentrações $0,25,50,75$ e $100 \%$ de $\mathrm{NH}_{4} \mathrm{NO}_{3}$ e $\mathrm{KNO}_{3}$ do meio MS (13) acrescido de $3 \mathrm{mg} . \mathrm{L}^{-1}$ de ácido giberélico $\left(\mathrm{GA}_{3}\right)$ e $6 \mathrm{mg} \cdot \mathrm{L}^{-1}$ de benzilaminopurina (BAP), solidificado com $7 \mathrm{~g} . \mathrm{L}^{-1}$ de ágar e $\mathrm{pH}$ ajustado para 5,8 antes da autoclavagem a $121^{\circ} \mathrm{C}$ e $1,1 \mathrm{~atm}$ por 20 minutos. Os explantes foram inoculados em câmara de fluxo laminar e mantidos em sala de crescimento com temperatura de $27 \pm 1^{\circ} \mathrm{C}$, fotoperíodo de 16 horas e 32 $\mathrm{mM} . \mathrm{m}^{-2} \cdot \mathrm{s}^{-1}$ de intensidade luminosa. O delineamento experimental foi inteiramente casualizado em esquema fatorial $5 \times 5$, com quatro repetições, três tubos por parcela, perfazendo um total de 100 parcelas, cada tubo contendo um explante. Para a análise estatística, utilizou-se o software Sisvar (6), e os tratamentos comparados através de regressão polinomial. Após 60 dias avaliaram-se número total de brotos e peso da matéria fresca e seca da parte aérea, constituídas das brotações com as respectivas folhas. Para obtenção do peso da matéria seca utilizou-se estufa de secagem na temperatura de $60^{\circ} \mathrm{C}$ por 72 horas.

\section{RESULTADOS E DISCUSSÃO}

$\mathrm{Na}$ interação entre as fontes de $\mathrm{N}$, somente a utilização de $75 \%$ da concentração de $\mathrm{KNO}_{3}$, no meio de cultura, promoveu aumento no número total de brotos $(2,87 \mathrm{~cm})$ até a concentração de $95,74 \%$ de $\mathrm{NH}_{4} \mathrm{NO}_{3}$ (Figura 1).

Quando se utilizou somente o $\mathrm{KNO}_{3}$, como fonte de N, o número total de brotos foi mínimo. Quando o $\mathrm{N}$ é fornecido somente na forma de nitrato a quantidade desse nutriente no meio de cultura é abundante no início do estabelecimento do explante. Entretanto, com o crescimento do explante, o meio de cultura começa a apresentar deficiência desse nutriente. Quando o N é fornecido nas formas de nitrato e amônio, inicialmente o $\mathrm{N}$ na forma nítrica é consumido mais rapidamente e, posteriormente, o $\mathrm{N}$ na forma amoniacal torna-se disponível para ser consumido pelo explante. Em trabalho realizado com Cycas revoluta (15), não obteve-se indução de brotações quando esta foi cultivada em meio contendo nitrato como única fonte de N. Desta forma fica evidenciada a essencialidade da combinação de ambas as fontes no cultivo in vitro (19). 
RIBEIRO, L.S. et al. Fontes de nitrogênio na micropropagação...

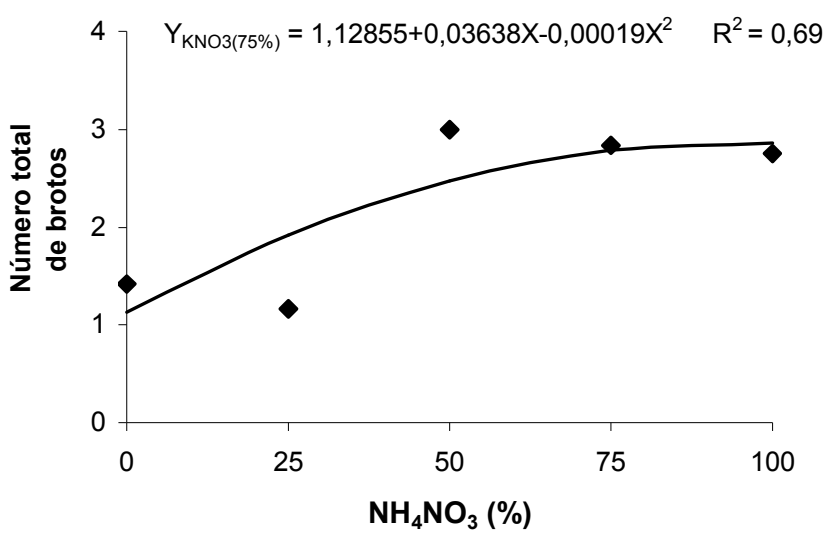

FIGURA 1 - Número total de brotos em segmentos nodais de Coffea arabica L. cv. Rubi, inoculados em meio MS com $75 \%$ de Nitrato de Potássio em concentrações crescentes de Nitrato de Amônio.

As concentrações de 75 e $100 \%$ de $\mathrm{KNO}_{3}$ promoveram acréscimos significativos no peso da matéria fresca da parte aérea até a concentração de $\mathrm{NH}_{4} \mathrm{NO}_{3}$ de $54 \%$ e $47 \%$, respectivamente (Figura 2). Pode-se deduzir que concentrações superiores a $50 \%$ de $\mathrm{NH}_{4} \mathrm{NO}_{3}$ não são necessárias para esta variável, enquanto concentrações superiores a $75 \%$ de $\mathrm{KNO}_{3}$ da recomendação padrão do meio de cultura, não são eficientes para obtenção de maior peso da matéria fresca da parte aérea de explantes de Coffea arabica L.

Quando o N é fornecido somente na forma de sais inorgânicos de amônio, as células in vitro apresentam sintomas de toxidez (7). Entretanto, a mesma concentração de amônio, que é inibitória quando a concentração de nitrato é baixa, permite bom crescimento quando aumenta a sua concentração (3). Houve decréscimo de 40,7\% na matéria fresca de Endive cv. Pancalieri castello quando submetida à baixa relação de $\mathrm{NH}_{4}^{+}: \mathrm{NO}_{3}^{-}$(17). Melhores resultados para peso de matéria fresca de brotos de batata doce foram obtidos ao serem cultivados com nitrato de amônio quando comparado com outras fontes de $\mathrm{N}(5)$.

$\mathrm{O}$ peso da matéria seca da parte aérea aumentou linearmente com o incremento das concentrações de Nitrato de Amônio (Figura 3) e Nitrato de Potássio (Figura 4).

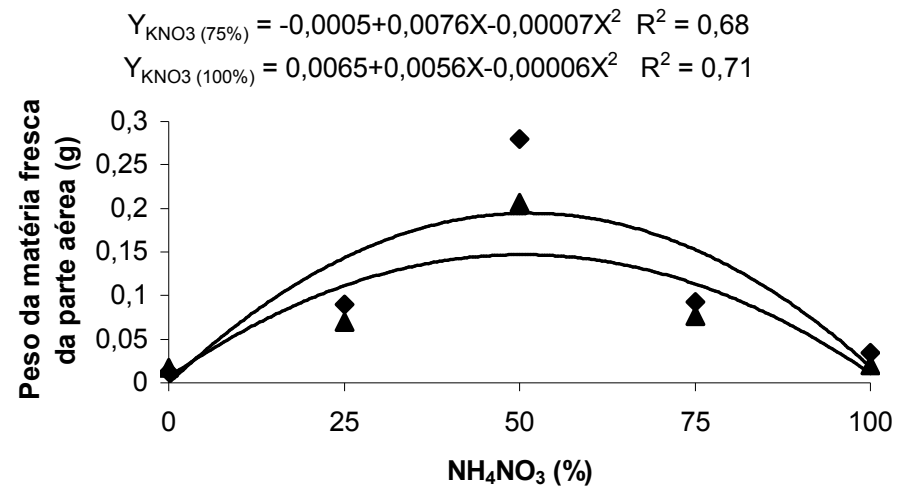

- $\mathrm{KNO}_{3}(75 \%)$

$\Delta \mathrm{KNO}_{3}(100 \%)$

FIGURA 2 - Peso da matéria fresca da parte aérea de segmentos nodais de Coffea arabica L. cv. Rubi, inoculado em meio MS com 75 e 100\% de Nitrato de Potássio em concentrações crescentes de Nitrato de Amônio. 
RIBEIRO, L.S. et al. Fontes de nitrogênio na micropropagação...

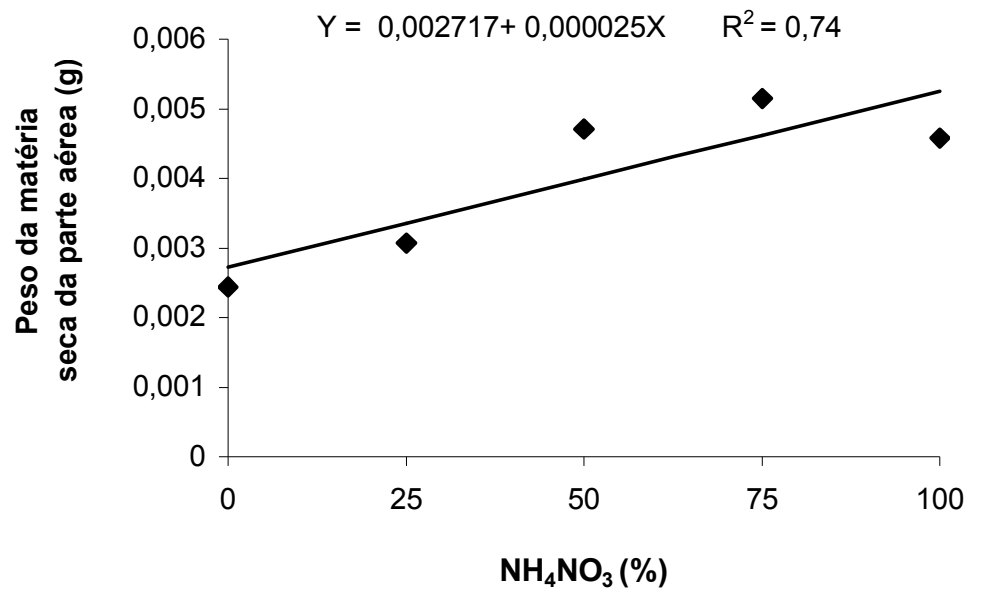

FIGURA 3 - Peso da matéria seca da parte aérea de segmentos nodais de Coffea arabica L. cv. Rubi, inoculados em meio MS, em concentrações crescentes de Nitrato de Amônio.

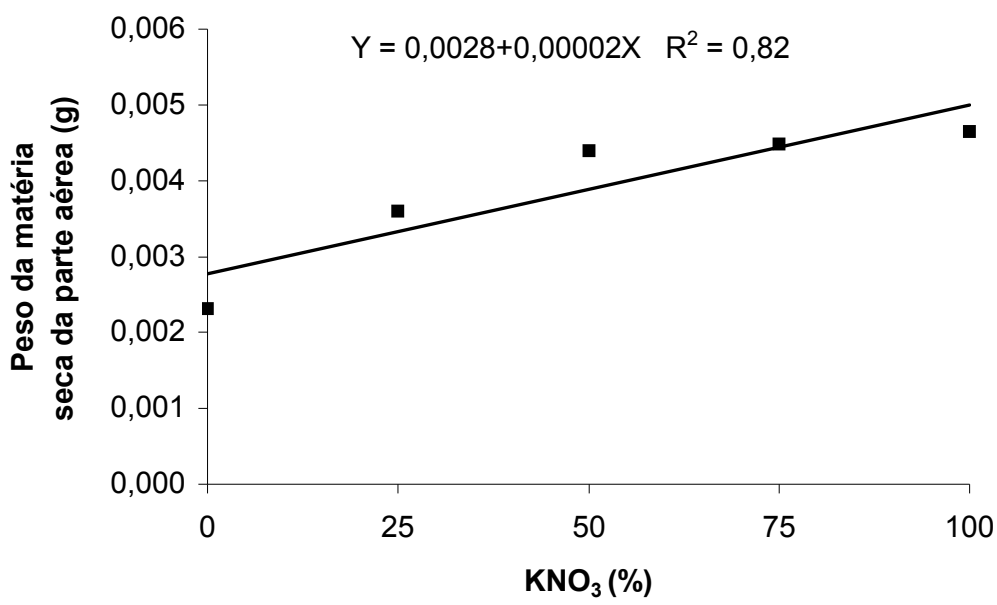

FIGURA 4 - Peso da matéria seca da parte aérea de segmentos nodais de Coffea arabica L. cv. Rubi, inoculados em meio MS, em concentrações crescentes de Nitrato de Potássio. 
RIBEIRO, L.S. et al. Fontes de nitrogênio na micropropagação...

O nitrato, como única fonte de $\mathrm{N}$, sustenta uma satisfatória taxa de crescimento em muitas espécies, sendo, também, a melhor forma de suprimento de $\mathrm{N}$ para algumas culturas (4). Embora haja relatos de que quando o $\mathrm{N}$ é fornecido somente na forma de sais inorgânicos de amônio, as células in vitro apresentam sintomas de toxidez $(7,19)$, no presente trabalho não foi verificado esse comportamento no peso da matéria seca da parte aérea.

Os resultados confirmam citações $(12,16)$ de que o $\mathrm{N}$ é um dos elementos essenciais e ativos para diversos processos metabólicos da planta. Existe uma relação ótima de nitrato/amônio, a qual promove maior assimilação em $\mathrm{N}$ comparada à assimilação do $\mathrm{N}$ fornecida por nitrato ou amônio isolados (11).

Deve-se considerar também que a alta concentração de sais do meio MS, comparada a outros meios, especificamente dos níveis de amônio e nitrato, pode ser crítica no processo de morfogênese e crescimento (16), sendo a demanda energética fornecida pelo metabolismo de carboidratos e a assi- milação destes íons diretamente relacionada ao sucesso da cultura in vitro $(12,16)$.

\section{CONCLUSÕES}

Em comparação à proporção original de soluções com nitrogênio, componentes de meios de cultura, fornecidas como $\mathrm{KNO}_{3}$ e $\mathrm{NH}_{4} \mathrm{NO}_{3}$, utilizadas para crescimento de segmentos nodais de Coffea arabica cv. Rubi, conclui-se que:

- O maior crescimento de brotos de cafeeiro é obtido com até 75 e até $95 \%$ das concentrações originais de $\mathrm{KNO}_{3}$ e $\mathrm{NH}_{4} \mathrm{NO}_{3}$;

- A parte aérea tem melhor crescimento, quando as concentrações das soluções nitrogenadas estão entre 75 a $100 \%$ para $\mathrm{KNO}_{3}$ e 50 a $100 \%$ para $\mathrm{NH}_{4} \mathrm{NO}_{3}$, comparadas à solução original.

\section{REFERÊNCIAS BIBLIOGRÁFICAS}

1 ANDRADE, L.M.C.O.; PEREIRA, A.B.; MACIEL, A.L.R.; PASQUAL, M. Influência de reguladores de crescimento na micropropagação 'in vitro' da cultivar Catuaí Vermelho LCH 2077-2-5-44. In: III INTERNATIONAL SEMINAR ON BIOTECHNOLOGY IN THE COFFEE AGROINDUSTRY, Londrina-PR, 1999, p. 68.

2 ARAUJO, R.N. de; CARVALHO, G.R.; FORNI, R.C.; PASQUAL, M. Influência dos sais minerais e benzilaminopurina sobre a multiplicação 'in vitro' de brotações do cafeeiro cv. Catuaí. In: VI CICESAL, Lavras-MG, 1993, p. 1.

3 CALDAS, R.A.; CALDAS, L.S. Nitrate, ammonium and kinetin effects on growth and enzyme activities of Paul's Scarlet Rose callus. Physiologia Plantarum, v.37, p.111-116, 1976.

4 CALDAS, L.S.; HARIDASAN, P.; FERREIRA, M.E. Meios nutritivo. In: TORRES, A.C.; CALDAS, L.S.; BUSO, J.A. (eds.). Técnicas e aplicações da cultura de tecidos de plantas. Brasília: ABCTP/EMBRAPA, 1998. p.87-132.

5 EL-SHABASI, M.S.S; EL-BAHR, M.K. Effect of potassium and nitrogen sources in tissue cultures of sweet potato. Egyptian Journal of Horticulture, v.26, p.267-279, 1999.

6 FERREIRA, D.F. Análises estatísticas por meio do Sisvar para Windows versão 4.0. In: REUNIÃO ANUAL DA REGIÃO BRASILEIRA DA SOCIEDADE INTERNACIONAL DE BIOMETRIA, 45, 2000, São Carlos. Anais. São Carlos, UFSCar, 2000. p.255-258.

7 GAMBORG, O.L.; SHYLUK, J. The culture of plant cells with ammonium salts as the sole nitrogen source. Plant Physiology, v.45, p.598-600, 1970.

8 GEORGE, E.F. Plant propagation and micropropagation. In: GEORGE, E.F. (ed.) Plant Propagation by Tissue Culture: part 1 The technology. 2ed. Somerset: England Exegetics, 1993. Cap.2, p. 37-66.

9 GEORGE, E.F.; SHERRINGTON, P.D. Plant propagation by tissue culture-Handbook and direction of commercial laboratories. Exegetics: Eversley, 1984.593p.

10 GRATTAPAGLIA, D.; MACHADO, M.A. Micropropagação. In: TORRES, A.C.; CALDAS, L.S.; BUSO, J.A. Cultura de tecidos e transformação genética de plantas. Brasília: CBAB/EMBRAPA. CNPH, 1998. p.183-260.

11 LEWIS, O.A.M.; JAMES, D.M.; HEWITT, E.J. Nitrogen assimilation in Barley (Hordeum vulgare L. cv. Mazurka) in response to nitrate and ammonium nutrition. Annals of Botany, v.49, p. 39-49, 1982.

12 MAGALHÃES, J.R.; WILCOX, G.E. Interação entre formas de nitrogênio e reguladores de crescimento. Pesquisa Agropecuária Brasileira, v.22, p. 576-585, 1987.

13 MURASHIGE, T.; SKOOG, F. A revised medium for rapid growth and bioassays with tobacco tissue cultures. Physiologia Plantarum, v.15, p.473-479, 1962.

14 REZENDE, E.; PASQUAL, M.; CARVALHO, G.R.; GUIMARÃES, R.J.; SCARANTE, M.J. Influência do fungicida triadimenol e benzilaminopurina na proliferação de brotos 'in vitro' do cafeeiro cv. Catuaí. In: $22^{\circ}$ CONGRESSO BRASILEIRO DE PESQUISAS CAFEEIRAS, Águas de Lindóia-SP, 1996, p. 40.

15 RINALDI, L.M.R. Factors affecting shoot regeneration from zygotic embryo and seedling explants of Cycas revolute Thunb. In Vitro Cellular and Development Biology Plant, v.35, p.25-28, 1999.

16 SAKUTA, M.; KOMAMINE, A. Cell grow and accumulation of secondary. In: CONSTABEL, F.; VASIL, I.K. (eds.), Cell Culture and Somatic Cell Genetics of Plants: Cell Culture in Phytochemistry. San Diego: Academic Press, 1987. v.4, cap. 5 , p. 97-114. 
RIBEIRO, L.S. et al. Fontes de nitrogênio na micropropagação...

17 SANTAMARIA, P.; ELIA, A.; GONNELLA, M. NH4:NO3 ratio changes, withdrawal of $\mathrm{N}$ before the harvest and reduction of nitrate leaf content in endive. National Research Council. In: Proceedings of the $9^{\text {th }}$ International Congress on Soilless Culture. Bari, Italia. 1997. p.471-435.

18 VAN BEUSICHEM, M.L.; KIRKBY, E.A.; BAAS, R. Influence of nitrate and ammonium nutrition and the uptake, assimilation, and distribution of nutrients in Ricinus communis. Plant Physiology v.86, p.914-921, 1988.

19 YATAZAWA, M.; FURUHASHI, K. Nitrogen sources for the growth of rice callus tissue. Soil Science and Plant Nutrition, v.14, p.73-79, 1968.

Recebido em 12/12/2001

Aceito em 11/12/2002 